\title{
Pemikiran Hukum Islam Ibnu Taimiyah
}

\author{
Yasin
}

\begin{abstract}
Abstrak
Ibnu Taimiyah adalah Taqiy al-D $D^{3} n$ Abu al-Abbâs Ahmad 'Abd al-Hal'm bin al-Imâm Majd al-D³n Abi al-Barakah 'Abd al-Salâm bin Muhammad al-Khudari bin 'Abd. Allah bin Taymiyah alHarran. Ia lahir pada hari Minggu tanggal 10 Rabi' al-Awwal $661 \mathrm{H}$. Bertepatan dengan tanggal 22 Januari 1263 M., lahir tahun sesudah Bagdad jatuh ke tangan Hulagu. Beliau dilahirkan di Harran yang terletak di sebelah utara Mesopotamia dan sebelah Tenggara Turki Modern. Produk pemikiran hukum Islam yang kita kenal dalam perjalanan sejarah Islam, yaitu kitab-kitab fikih, fatwa-fatwa ulama, keputusan-keputusan Pengadilan Agama dan Peraturan perundangan di negeri-negeri Muslim. masing-masing produk pemikiran hukum itu mempunyai ciri khas tersendiri, karena itu memerlukan perhatian tersendiri pula. Nama kitab beliau adalah kitab Majmu' al-Fatâwa Ibnu Taimiyah yang dikumpulkan atau disusun 'Abd. Al-Rahmân bin Muhammad bin Qâsim al-2imiy al-Najdiy al-Hanbaliy. Kitab ini terdiri dari 37 jilid yang merupakan kumpulan fatwa dari ber- bagai kitab, surat dan pendapat pendapat yang ia hadapi pada masanya.
\end{abstract}

\section{Pendahuluan}

Ibnu Kat ${ }^{3}$ r berkata, Syaikhul Islam Ibnu Taimiyah adalah salah satu dari ulama besar dan termasuk orang yang bisa benar juga bisa salah. Namun bila kesalahannya dibandingkan dengan yang benar, maka

\footnotetext{
Tulisan Ibn Taimiyah terdapat pada Ensiklopedi Hukum Islam dengan tulisan Ibnu Taimiyah. Yang berarti telah menjadi bahasa pepuler, sehingga pada tulisan selanjutnya pada makalah ini ditulis dengan Ibnu Taimiyah. Abdul Azis Dahlan, dkk. Ensiklopedi Hukum Islam, Jilid 2, Cet. I, (Jakarta: PT. Ichtiar Baru Van Hoeve, 1997), h. 623.
} 
ibarat setetes air yang dimasukkan ke dalam lautan luas, karena kesa- lahan tersebut pasti diampuni.

Al-Hafiz Ibnu Hajar berkata, walaupun begitu, Ibnu Taimiyah adalah seorang manusia yang bisa salah dan benar. Maka apa yang benar dan itu yang terbanyak, harus diambil dan diperhatikan, sedangkan yang salah maka jangan diikuti, namun dia dimaafkan. Sebab para imam di masa beliau mengakui bahwa semua syarat boleh berijtihâd sudah ada pada diri mereka.

Lebih lanjut beliau berpendapat bahwa pribadi Ibnu Taimiyah lebih bersinar dari pada matahari. Pemberian gelar Syaikhul Islam kepada beliau masih tetap abadi sampai sekarang dan gelar ini akan selalu abadi sampai masa yang akan datang. Sebagaimana gelar itu telah abadi di masa silam. Tidak ada orang yang akan mengingkari gelar ini kecuali orang yang tidak mengetahui kapasitas dirinya.

Ibnu Taimiyah adalah sosok menumental sepanjang sejarah. Umat ini sangat membutuhkan pribadi multidimensi seperti beliau, ber- wawasan luas, visioner dan tak kenal menyerah. Beliau adalah pro- totipe ulama pembaharu yang memiliki pemahaman Islam yang ori- sinil dan mendalam. Ilmu dan amalnya senantiasa membawa mamfaat dan kemaslahatan bagi umat.

Ibnu Taimiyah pernah berkata:

Sepanjang hidup hingga sekarang, aku tidak pernah mengajak seorang pun dalam masalah dasar-dasar agama, seperti permasalahan mentauhidkan Allah, meyakini sifat-sifatnya, takdir, kenabian, hari kiamat dan dalil-dalilnya, kepada mazhab Hanbali atau bukan Hanbali. Aku tidak pernah membela dan tidak pernah menyebutkannya dalam perkataanku. Aku juga tidak pernah menyebutkan kecuali apa yang telah disepakati oleh kaum muslimin terdahulu dan imam-imam salaf. Aku sering mengatakan bahwa aku memberi tempo selama tiga tahun kepada orang yang tidak sependapat denganku. Di samping itu, semua orang juga tahu bahwa aku adalah orang yang paling menghindari me-

Said Abdul Azhim, Ibnu Taimiyah al-Tajdîd al-Salafì wa Dakwa alIslâhîyah, yang diterjemahkan oleh Faisal Saleh dkk., dengan Judul Ibnu Taimiyah Pembaharu Salafi dan Dakwa Reformasi, Cet. I, (Jakarta: Pustaka Al-Kautsar, 2005), h. 6.

Ibid., h. 7 
nisbatkan seseorang tertentu kepada kekufuran, kefasikan dan kemaksiatan, kecuali jika benar-benar sudah diketahui bahwa ada dalil pasti yang menyatakan orang tersebut kafir, fasiq, atau berbuat maksiat.

Dengan kepribadian yang menurut sementara orang eksentrik dan kontroversial, Ibnu Taimiyah adalah penulis yang sangat subur, dengan warisan karya tulis yang berjumlah ratusan dengan bahasa yang tegas, keras, kadang-kadang bombastis dan hiperbolik, sehingga banyak menarik sikap-sikap pro-kontra yang juga keras dari masyarakat.

Maka dari itu, makalah ini menguraikan dan mengkaji tentang ba- gaimana ijtihad hukum Ibnu Taimiyah.

\section{Pembahasan}

\section{a. Biografi Ibnu Taimiyah (661-728 H./1260-1328 M.)}

Nama lengkap Ibnu Taimiyah adalah Taqiy al-D³n Abu al-Abbâs Ah- mad 'Abd al-Hal³m bin al-Imâm Majd al-D³n Abi alBarakah 'Abd al-Salâm bin Muhammad al-Khudari bin 'Abd. Allah bin Taymiyah al-Harran. Ia lahir pada hari Minggu tanggal 10 Rabi' al-Awwal $661 \mathrm{H}$. Bertepatan dengan tanggal 22 Januari 1263 M., lahir tahun sesudah Bagdad jatuh ke tangan Hulagu Khan. Beliau dilahirkan di Harran yang terletak di sebelah utara Mesopotamia dan sebelah Tenggara Turki Modern.

Keluarga Ibnu Taimiyah berimigrasi ke Damaskus ketika dia ber- usia 5 tahun $(667 \mathrm{H} / 1268 \mathrm{M})$, dengan membawa kitab-kitab yang ber- harga dengan menggunakan beberapa pedati yang ditarik lembu un- tuk menghindari kekejaman Mongol. Ibnu Taimiyah dilahirkan dari keluarga yang terhormat, zuhud, wara,' dan takwa. Ayahnya dikenal sebagai pengajar dan penghapal hadis, mufassir, ahli ilmu uşül, dan ilmu nahwu.

Ibid., h. 8.

Lihat Dewan Redaksi Ensiklopedi Islam, Ensiklopedi Islam, (Cet.III; Jakarta: Ichtiar Baru Van Hoeve, 1994), h. 168-169. Lihat pula Cyrill Glasse, The Concise Encyclopedia of Islam, diterjemahkan oleh Ghufran A. Mas'adi dengan judul Ensiklopedi Islam (Ringkas), Cet. II (Jakarta PT. Raja Grafindo Persada, 1999), h. 155-156.

Ibid. 
Dengan demikian, Ibnu Taimiyah belajar menghapal al-Quran dari ayahnya, mempelajari dan menghapal hadis. Muş̧̧alahò al-Hadis alJarh wa al-Ta'dil, tafsir, fikih, uşül al-fiqh, mantik, filsafat, kalam, aljabar, ilmu hitung, kimia dan ilmu falak.

Lingkungan tersebut telah membentuk kepribadian Ibnu Taimiyah dengan mempelajari ilmu-ilmu yang hidup dan berkembang pada zamannya, sehingga ilmu yang dipelajarinya berkembang sedemikian rupa. Dengan kapasitas intelektual yang amat besar, sejak kecil Ibnu Taimiyah telah menunjukkan berbagai kemampuan yang luar biasa, sehingga dalam umur belasan tahun ia sudah dipercaya untuk sekali menggantikan ayahnya memberi kuliah di universitas masjid terse- but.

Pada awal abad ke-8 Hijriyah, seperti abad-abad sebelumnya, umat Islam terpecah ke dalam negara-negara kecil. Raja-raja negara tersebut memandang satu sama lain sebagai musuh yang setiap saat saling memerangi; mereka tidak lagi terkait dengan ajaran agama yang menyatakan bahwa muslim dengan muslim lainnya adalah saudara.

Ibn Aśrar sebagaimana dikutip Jaih Mubarok menggambarkan situasi ketika itu sebagai berikut:.

"Pada zaman ini, Islam dan umat Islam mengalami bencana yang belum pernah menimpah umat lain sebelumnya, yaitu bencana yang diakibatkan oleh serangan Tartar dari arah timur; sedangkan dari arah barat muncul Eropa yang menyerbu Syam menuju Mesir. Di tengah-tengah dua serangan tersebut, umat Islam saling memfitnah. ${ }^{10}$

Gambaran di atas kemudian dikomentari oleh Juhaya S. Pradja sebagaimana dikutip Jaih Mubarok, ${ }^{11}$ bahwa gambaran yang dikemukakan oleh Ibn Asrar menunjukkan bahwa keadaan umat Islam kala itu sangat menyedihkan. Dari timur, mereka diserang Tatar; dari barat, mereka diserang Eropa (Barat) yang dikenal dengan orang-orang sa-

\footnotetext{
Ibid.

Ibid.

Ibid.
}

10 Jaih Mubarok, Sejarah dan Perkembangan Hukum Islam, Cet. I, (Bandung: PT. Remaja Rosdakarya 2000), h. 170.

11 Ibid. 
lib; dan secara internal umat Islam dikacaukan dan digerogoti oleh permusuhan di antara para penguasa dan sekte-sekte Islam.

Keadaan seperti itu dialami oleh Ibnu Taimiyah. Meskipun memiliki kemampuan dan dipandang berkompeten, ia (sebagai seorang pegawai) sering diangkat dan diberhentikan hingga berpuluh kali. ${ }^{12}$

Ibnu Taimiyah menyaksikan perang yang berkepanjangan disertai pembauran unsur-unsur kehidupan dan suku bangsa yang beragam. Perang salib berakibat pada kontak Barat dan Timur dalam banyak hal, seperti kontak peradaban, adat-istiadat, dan agama.

Perang al-Darus telah mengacaukan kehidupan umat Islam. Orang Irak berevakuasi ke Damaskus; orang Damaskus berevakuasi ke Me- sir bahkan ke Maroko. Dalam kondisi seperti itu, Ibnu Taimiyah bertahan di Damaskus bersama umat Islam yang lemah, yang hidup tanpa pemimpin karena ditinggalkan oleh rajanya akibat ganasnya serangan Tartar di Damaskus. ${ }^{13}$

Ulama pada zaman Ibnu Taimiyah mempunyai corak dan metode berpikir yang beragam. Di antara mereka ada yang berpengetahuan luas dalam bidang tafsir, hadis, fikih, dan kalam, meskipun hanya sampai pada derajat muttabi atau muqallid tabi'in.

Di tengah kejumudan berpikir, muncul ulama yang berusaha menyerasikan akal dengan wahyu, seperti Izz al- $D^{3} n$ bin Abd alSalâm dan Abu Hamid al-Ghazâli (450 H/1058 M). Di samping filsuf, muncul pula ahli tasawuf yang menggabungkan antara metode filosofis rasional dengan kebersihan spiritual. Di samping itu, muncul pula aliran-aliran tarekat yang membimbing masyarakat umum yang mengakibatkan munculnya kultus individu.

\section{b. Karya Ilmiah Ibn Taimiyah}

Sedikitnya ada empat macam produk pemikiran hukum Islam ${ }^{14}$ yang

12 Carl Brockelmann, History of Islamic Peoples, (London: Rouledge \& Kegan Paul Limited, 1994), h. 237.

13 Ibid., h. 148-149.

14 Lihat Atho'Mudzhar, "Fiqh dan Reaktualisasi Ajaran Islam", dalam Budhy Munawar Rachamn (Ed), Kontekstualisasi Doktrin Islam dalam Sejarah, Cet II, (Jakarta: Paramadina, 1995), h. 369. 
kita kenal dalam perjalanan sejarah Islam, yaitu kitab-kitab fikih, ${ }^{15}$ fatwa-fatwa ulama, ${ }^{16}$ keputusan-keputusan Pengadilan Agama, ${ }^{17}$ dan peraturan perundangan di negeri-negeri Muslim. ${ }^{18}$ masing-masing produk pemikiran hukum itu mempunyai ciri khas tersendiri, karena itu memerlukan perhatian tersendiri pula.

Salah satu produk pemikiran hukum Islam adalah tataran fatwafatwa ulama adalah Kitab Majmu' al-Fatâwa Ibnu Taimiyah yang dikumpulkan 'Abd. Al-Rahmân bin Muhammad bin Qâsim al-22simiy al-Najdiy al-Hanbaliy. Kitab ini terdiri dari 37 jilid $^{19}$ yang merupakan kumpulan fatwa dari berbagai kitab, ${ }^{20}$ surat dan pendapat-

15 Lihat, Ibid., h. 370.

16 Ibid.

17 Ibid.

18 Ibid.

19 Jilid I tentang kitab $\operatorname{tauh}^{3} d$ al-Rububiyah, Jilid II tentang kitab Tauh ${ }^{3} d$ al-Uluhiyyah wa al-Rad 'Alâ Ittisal al-Hulül wa al-Ittihâd, Jilid III tentang Kitab Mujmal I'tiqâd alSalaf, Jilid IV tentang Kitab Mufasâl al-I'tiqâd, Jilid V tentang Kitâb al- Asmấ' wa alSifât, Jilid VI al-Juz al-Sâni min Kitâb al-Asmâ wa al-Sifât:

Jilid VII tentang al-Imân; Jilid VIII tentang al-Qadr, Jilid IX tentang al-Mantiq, Jilid X tentang illm al- Sulük;Jili XI tentang al-Tasawwwuf, Jilid XII tentang alQur'ân Kalâmullah Haq ${ }^{3} q a$ tuhu; Jilid XIII tentang Kitab Muqaddimah al-Tafs ${ }^{3}$, Jilid XIV tentang Kitab Tafsir al-Jiz 'al-Awwâl Min Sürah al-Fâtihah Ila Sürah al-A'raf, Jilid XV tentang Kitâb Tafs'r r al-Juz' al-Sâni Min surah al-A'râf Ilâ Surah al-Zumar, Jilid XVI tentang Kitab Tafs ${ }^{3}$ r al-Juz' al-Sâlis Min Sürah alZumar Ilâ Sürah al-Ikhlâs, Jilid XVII tentang Kitab Tafs'r al-Juz al-Râbi' Min Sürah al-Ikhlâsh wa al-Mauzatain; Jilid XVIII tentang Kitâb al- Had $^{3}$ s, Jilid XIX tentang Kitâb Usül al-fiqh Juz al- Ittiba; Jilid XX tentang Kitâb Usül al- Fiqh Juz al- Sâni al-Tamazhub, Jllid XXI tentang kutub al-Fiqh al-Juz al-Awwâl alTahârah; Jilid XXII tentang Kutub al-Fqih al-Juz al-Sâni al-Salât, Jilid XXIII tentang Kutub al-Fiqh al-Juz al-Sâlis sujud al Sahwi Ilâ Salât al-Aqhzâr; Jilid XXIV tentang Kutub al-Fiqh al-Juz al-Râbi' Min Salât ahl al-A'zari Ilâ al-Zakat, Jilid XXV tentang Kutub al-Fiqh al-Juz al-Khâmis al-Zakat wa al-Saum, Jilid XXVI tentang Kutub al-Fiqh al-Juz al-Sâdis al- Haj; Jilid XXVII tentang Kutub al-Fiqh al-Juz al-Sâbi' al-Ziyârah wa Syad al-Rihâl Ilaiha, Jilid XXVII tentang Kutub al-Fiqh al-Juz al-Sâmin al-Jihâd: Jilid XXIX tentang Kutub al-Fiqh alTâsi' al-Baiy; Jilid XXX tentang Kutub al-Sulh Ila al-Waqt, Jilid XXXI tentang

Kitab al-Waqt Ilâ al-Nikâh; Jilid XXXII tentang Nikâh: Jilid XXXIII tentang Kitab al-Talâq; Jilid XXXIV tentang Kitâb al-Zihâr Ilâ al- Qitâl Ahl al-Baqa; Jilid XXXV tentang Kitab al-Qitâl Ahl al-Baqa Ilâ Nahâyah al- Iqrâr; Jilid XXXVI tentang al-Fahâris al-Ammâh wa al-Taqr ${ }^{3}$ b, dan Jilid XXXVII tentang al-Fhâris al-Ammah wa al-Taqr ${ }^{3}$ b.

20 Adapun kitab-kitab dan kumpulan-kumpulan fatwa yang tercetak terlebih 
pendapat yang ia hadapi pada masanya. Kitab pertama yang ia temui atau dikumpulkannya adalah kitab Fatâwa Ulamâ Najd yang dimiliki oleh Muhammad bin 'Abd al-Lat' ${ }^{3} \mathrm{f}$ sebanyak tiga jilid. Selanjutnya, di Hijaz ia mendapatkan kitab Fatâwa Aimmah al-Da'wah al-Najdain terbitan al-Maktabah al-Haram al-Makiy. Selanjutnya penyunting kitab ini melakukan perjalanan ke berbagai negara seperti Paris, Mesir, Syam, Damaskus, Bagdad dan beberapa negara lainnya untuk mengumpulkan tulisan Ibn Taimiyah.

Kitab ini pertama kali dicetak pada tahun $1374 \mathrm{H}$ atas saran Raja Saudi dan telah dicetak ulang beberapa kali. Cetakan terakhir dan paling komprehensif diterbitkan di Saudi Arabia dalam 37 jilid.

\section{Metode Ijtihâd Ibnu Taimiyah}

Ibnu Taimiyah adalah sosok ulama yang hidup pada fase yang masyarakatnya hidup dalam taklid. ${ }^{21}$ Menurut Juhaya S. Praja, ${ }^{22}$ fase

dahulu dan termuat dalam kumpulan fatwa ini adalah al-Tawasul wa al-Was ${ }^{3} l a h$, al-Tadmiriyah, al-Wâsitiyah, al-hamawiyah, al-Madinah, Majmu'ah al-Rasâil wa al-Masâil al-Mun riyah Majmu'ah al-Rasâil wa al-Masâil, Ra's al-Husain, al-Siyâsah, al-Syar'iyah, al-Jawab al-Bâhir, Tafs ${ }^{3}$ ir Surah Sabbih, al-Qawaid alNuraniyah, Nazariyah al- 'Aqd, Majmu'ibnu Rumaih, Naqd al-Mantiq, Mukhtasar Nas³at al-Ikhwân 'An Mantiq al-Yunâni, al-Marid'niyah, Kitâb al'man, Syarh Had's Abu Zae, Syarh Had's al-Nuzül, Bayân al-Huda min al-Dalâl fiy Amr al-Hilâl, al-Fatâwa al-Misriyah, Manâsik al-Haj, 'Arba'üna Hadsan, Ba'd Syazarât al-Balât ${ }^{3} n$, l-Furqân Bayn Auliyâ al-Rahmân wa Auliyâ alSyaitân. Majmu'ah al-Rasâil wa al Masâil wa Fatâwa Syaikh al-Islâm, Tafs ${ }^{3} r$ sürah al-Ikhlâsh, Jawab Ahl al-Ilm wa al-'man ,Min Fatâwa Syaikh al-Islâm, alTuhqah al-'Iraqiyah, Muqadimah al-Tafs ${ }^{3} r$, al-Süfiyahwa al-Fuqârâ, Tafs ${ }^{3} r$ Sürah al-Nür, Tafdil Mazhab Ahl al-Mad³nah, al-Qabrasiyah, Qasidah al-Qadr, Naqd Maratib al-Ijmâ; dan al-Afâl al-Ikhtiyâriyah. Lihat " Abd al-Rahman Muhammad bin Qasim al-Assimiy, Majmu'al-Fatawa Syaikh al-Islam Ibnu Taymiyah, Juz I (Saudi Arabia: Mamlakah Saudi Arabia, 1398 M), h. 1-4.

21 Lebih jelas dapat dilihat 'Umar Sulaiman al-Asygar, Tarikh al-Figh al-Islami. (Amman: Dar al-Nafa'is, 1991), h.146-162. juga dapat dilihat Muhammad Kamil Musa, Al-Madhkal Ila al-Tasyri' al-Islam, (Beirut: Muasassah al-Risalah. 1989). H. 180. da lihat Muhammad 'Ali al-Sayyis, Nasy'ah al-Fiqh al-Ijtihadi wa Atwaruh, (t.tp; Majma' al-Buhus al-Ismiyyah, 1970), h. 374-376.

22 Juhaya S Praja, "Dinamika Pemikiran Hukum Islam" dalam Jaih Mubarok, Sejarah dan Perkembangan Hukum Islam, Cet. I, (Bandung: PT. Remaja Rosda- karya.2000), h. xvii. 
taklid merupakan fase terburuk bagi dinamika pemikiran hukum Islam karena terjadi disalokasi, yakni menempatkan gagasan ulama sejajar dengan al-Quran dan Sunnah, bahkan "lebih tinggi" dari al-Quran dan Sunnah. Maka dari itu, mengganti, mengubah atau meninggalkan pendapat imam mazhab yang dianut menjadi "haram". Kekeliruan itu terjadi karena pergeseran penghargaan terhadap ulama, yaitu dari ulama sebagai hamil al-lughah, kepada ulama sebagai syari'.

Selain itu, fenomena pada periode taklid adalah ketidakberanian intelektual yang berimplikasi pada mandeknya hukum Islam atau fikih $^{23}$ dan matinya kreativitas pemikiran Muslim yang disembelih di atas altar persatuan. Oleh karena itu, hukum Islam yang amat dinamis dan kreatif dalam perjalanan sejarahnya yang awal kini telah mengalami kemalangan serius dan sarat dengan muatan-muatan asing. Dalam konteks semacam inilah Ibn Taimiyah yang tersentuh panggilan keagamaan, muncul di atas panggung sejarah pembaruan hukum Islam dengan mengklaim hak ijtihâd mutlak bagi dirinya serta menyeru masyarakat Muslim untuk kembali ke akar spritual mereka, al-Quran dan Sunnah Nabi. Namun verifikasi keagamaan Ibnu Taimiyah hanya terbatas pengaruhnya di kalangan murid-muridnya seperti Ibnu Qayyim dan tidak pernah menjelma menjadi suatu gerakan pada masanya. Nanti setelah beberapa abad kemudian, yakni pada pengunjung abad ke-18, seruan Ibnu Taimiyah ${ }^{24}$ ditanggapi Muhammad bin 'Abd al-Wahhab (w. 1204 H./1791 M.) di Arabia dan Syah Wali Allah (w.1762 M.) di India. ${ }^{25}$

Ibnu Taimiyah, memang banyak mendapat kritik bahwa ia bukanlah seorang modernis atau mujtahid, ${ }^{26}$ ia hanyalah pengikut setia

23 Lihat, T.M. Hasbi Ash-Shiddieqy, Pengantar Hukum Islam, Vol. 1, (Jakarta: Bulan Bintang, 1980):idem, Syariat Islam Menjawab Tantangan Zaman, (Jakarta: Bulan Bintang1966) h.3,5. H.M. Rasyidi, Keutamaan Hukuk Islam,(Jakarta: Bulan Bintang, 1980). Sementara pengembangan teknologi fikih dan syariah dalam perjalanan historisnya, lihat Ash-Shiddieqy, "Pengantar", Vol. 1. h. 22-23; juga Ahmad Hasan, Pintu Ijtihad Sebelum Tertutup, terjemahan A. Garnadi, (Bandung: Pustaka, 1984), h. 1-10.

24 Lihat Taufik Adnan Amal, Islam dan Tantangan Modernitas: Studi atas Pemiki-ran Hukum Fazlur Rahman, Cet. V, (Bandung: Mizan, 994), h. 38.

25 Lihat Ibid., h. 37.

26 Lihat Nurcholish Madjid, Kaki Langit Peradaban Islam, Cet. I, (Jakarta: Para- 
Imam Ahmad bin Hanbal. Namun, ia adalah salah satu tokoh dari se- kian banyak tokoh pemikir Islam klasik yang menjadi rujukan kaum Muslim di zaman modern dan sangat menonjol. ${ }^{27}$ Ibnu Taimiyah juga pernah menyerang 'Umar bin al-Khattab sebagai orang yang banyak melakukan kesalahan. ${ }^{28}$ Sebaliknya, ia sempat menunjukkan kelebihan tokoh yang sangat kontroversial, semisal, Muawiyah bin Abu Sufyan dan Yazid, anaknya. ${ }^{29}$ Namun beberapa pendapatnya di bidang hukum Islam sangat berharga sebagai embrio kebangkitan kembali ijtihâd, di antaranya ; 1) mengingkari ijma' tidaklah kafir; 2) orang yang tidak sembahyang tidak boleh diberi zakat; dan 3) boleh tayamum walaupun ada air untuk shalat jika waktu shalat akan habis jika berwudhu. ${ }^{30}$

Ibnu Taimiyah dalam sistematika hukum atau sumber hukum ij- tihad adalah berbeda dengan Ahmad bin Hanbal yang dianggap seba- gai pelanjutnya. Untuk itu di bawah ini dibedakan sumber hukum mereka:

\begin{tabular}{|l|l|}
\hline Ahmad bin Hambal & Ibnu Taimiyah \\
\hline $\begin{array}{c}\text { 1. Nash, yakni al-Quran dan } \\
\text { sunnah sebagai sumber (dalil) } \\
\text { yg utama dan pertama }\end{array}$ & $\begin{array}{l}\text { 1. Al-Quran sebagai sumber } \\
\text { hukum pertama dan utama }\end{array}$ \\
\hline $\begin{array}{l}\text { 2. Fatwa sahabat, terutama yang } \\
\text { disepakati }\end{array}$ & 2. Hadis \\
\hline $\begin{array}{l}\text { 3. Hadis mursal dan hadis daif } \\
\text { selama tidak bertentangan } \\
\text { dengan al-Quran }\end{array}$ & 3. Ijma' \\
\hline $\begin{array}{l}\text { 4. Qiyas digunakan bila tidak ada } \\
\text { hadis atau fatwa para sahabat }\end{array}$ & 4. Qiyas \\
\hline
\end{tabular}

Dengan gambaran di atas jelas berbeda pandangan dengan Ahmad Ibnu Hanbal yang mana Ibnu Taimiya tidak mengambil hadis mursal madina, 1997), h. 120.

27 Ibid.

28 H.A.R. Gibb dan J.H. Kramers, "Ibn Taymiyah", Shorter Encyclopedia of Islam, (Leiden: E.J. Brill-London LUZA \& CO, 1961),H. 152.

29 LIhat Nurcholish Madjid (Ed), Khasanah Intelektual Islam, (Jakarta: Bulan Bintang, 1984), h. 41.

30 Lihat Atho Mudzhar, Membaca Gelombang Ijtidad: Antara Tradisi dan Liberasi, Cet. I, (Jakarta: Titian Ilahi Press, 1998), h. 84. 
dan hadis daif, juga fatwa sahabat, tetapi beliau lebih mengutamakan al-Quran sebagai sumber pertama, menyusul Hadis, Ijma, dan Qi- yas.

Bahkan Ibnu Taimiyah berpendapat bahwa setiap masalah yang diputuskan berdasarkan ijma dan tidak ada lagi perselisihan di antara orang-orang mukmin, dianggap sebagai petunjuk yang di dalamnya terkandung penjelasan dari Allah. Siapa yang menentang ijma' ini berarti dia sama dengan menentang nash yang sudah jelas. Apabila disangkakan ada ijma' dan tidak ada keputusan yang tetap yang ber- arti juga tidak ditetapkan petunjuk dari Rasul, maka orang yang me- nentang ijma' tidak dianggap sebagai kafir. Bahkan persangkaan adanya ijma' merupakan tindakan yang salah. Adapun yang benar adalah kebalikannya. Inilah keputusan tentang siapa yang dianggap kufur karena berseberangan dengan ijma' (artinya jika kesamar-samaran ijma' karena adanya dalil yang berbeda, maka jika ada pendapat yang berbeda dengan ijma', tidak dianggap sebagai kufur. Lain halnya jika ijma' itu sudah jelas dan pasti, yang menentang dianggap kufur). Be- gitu pula firman Allah. ${ }^{31}$

Selanjutnya dalam mencari hukum yang ada dalam al-Quran, ulama usül menempuh dengan jalan; 1) Istinbât dengan memahami nas yang jelas (qat'iy); 2) Ijtihâd terhadap nas yang belum menunjukkan hukum suatu masalah; 3) Ijtihâd juga dalam memahami masalah yang hanya ditunjuki oleh jiwa nas yakni kemaslahatan.

Formulasi tersebut dituangkan ke dalam tiga istilah, yakni 1). Ijtihâd bayani (al-Ijtihâd al-Bayâni), yaitu ijtihad yang berhubungan dengan penjelasan kebahasaan yang terdapat dalam al-Quran dan Sunnah; 2). Ijtihad qiyâsi (al-Ijtihâd al-Qiyâsi), yaitu ijtihâd untuk menyelesaikan suatu permasalahan yang di dalam al-Quran dan Sunnah tidak terda- pat ketentuan hukumnya, dan ulama menyelesaikannya dengan cara qiyâs dan istihsân. Ijtihâd qiyâsi biasa disebut pula dengan al-ijtihâd dengan menggunakan ra'yi yang tidak menggunakan ayat-ayat al-Quran atau Sunnah tertentu secara khusus, tetapi ijtihâd itu berpegang kepada "ruh al-syariat" yang ditetapkan dalam semua ayat

31 Ibnu Taimiyah, Al-Imam, yang diterjemahkan oleh Kathur Suhardi, Cet. III, (Jakarta: Darul Falah, 2007), h. 31. 
al-Quran dan Sunnah secara umum.

\section{a. Ijtihâd Bayâni}

Secara umum, ijtihâd bayâni dapat dibedakan menjadi tiga. Pertama, ijtihad yang berhubungan dengan cakupan makna lafaz, yang meli- puti al-khas dan al- 'âm (khusus dan umum). Selanjutnya, lafaz khas sendiri terdiri atas al-mutlaq wa al-muqayyad dan al-amr wa al-nahy. Kedua, ijtihâd yang berhubungan dengan penggunaan lafaz, yang dapat dibedakan menjadi empat, yaitu al-haqiqat (hakikat) dan al-Majaz (majaz). Di antara al-haqiqat dan al-majaz terdapat yang sarih dan alkinayat. Ketiga, ijtihâd yang berhubungan dengan cara penunjukan makna lafal terhadap makna (dilâlah), yang meliputi a). penunjukan lafal terhadap makna segi cakupannya terdiri dari 1) dilâlat al-mutabaqat, yakni lafal yang menunjukkan pada kesem- purnaan makna sesuai dengan pengertian awalnya; 2) dilâlat al-tadamum, yakni lafal yang menunjukkan kepada sebagian makna yang dicakupnya; 3) dilâlat alIltizâm, yakni penunjukan lafaz kepada kemestian berdasarkan akal atau kecerdasan yang tidak tertolak dari segi maknanya. b). penunjukan lafal terhadap kejelasan dan kesamaran makna lafal yang terdiri dari khafiy dilâlat dan zahir al-dilâlat yakni lafal yang maknanya tersembunyi karena diri (zatnya) atau persoalan lain. Khafiy dilalat terdiri atas empat macam, yaitu al-mutasyabihât, al-Mujmal, al-Musyikil dan al-Khafiy. Sedangkan zahir al-dilâlat terdiri atas al-nas, al-mufassar dan almuhkam, c) penunjukan lafaz terhadap makna dengan pendekatan dilâlat al-Iqtirân dan dilâlat al-Ilhâm. ${ }^{32}$

Dengan memperhatikan uraian yang berkenaan dengan ijtihâd bayani tersebut, penulis berkesimpulan bahwa Ibnu Taimiyah dalam melakukan fatwa menggunakan metode ijtihâd bayâni dengan bebe- rapa argumen:

Pertama, Ibnu Taimiyah menggunakan ijtihad yang berhubungan dengan cakupan makna lafaz, yang meliputi al-khas dan al-am (khusus dan umum). Kedua, lafaz khas sendiri terdiri atas al-mutlaq wa al-

32 Muhammad Salam Madkur, Manahij al-Ijtihad fiy al-Islam, (Kuwait: Universitas Kuwait, 1974), h. 396. lihat pula Muhammad Ma'aruf al-Dawalibi, Al-Madkhal Ila al-Tasyri' al-Islami, (Beirut: Mu'assasah al-Risalah, 1989), h. 107. 
muqayyad dan al-amr wa al-nahy. ${ }^{33}$

Suatu teori tentang al-âm yang ia kemukakan misalnya adalah:

$$
\begin{aligned}
& \text { و اللفظ العام ان اريد به الخاص فلا بلد من نصب دليل يدل على التخصيص } \\
& \text {, اما مقترن بالخطاب عند من لا يجوز تاخير البيان , واما مو ســع في تاخيره } \\
& \text { الى حين الحلاجة عند المجمهور. و لا شك ان المخاطبين هذا على عهد رسول } \\
& \text { الله ص . م. كانو ا محتاجين الم معرفة حكم اللخطاب , فلو كان المراد باللفظ } \\
& \text { العام في لعنة اكل الربا والمحلل ونحو هما البحمع على بتحريمه ـو ذذلك لا يعلم الا } \\
& \text { بعد موت النبى ص.م. وتكلم الامة في جميع افر اد ذلك العام . لكان قد اخر } \\
& \text { بيان كلامه الى ان تكلم جهيع الامة في جهيع افراده ,و وهذا لا يجوز. }
\end{aligned}
$$

Dan lafaz âm, jika dikehendaki al-khas, maka khas ada dalil yang menunjukkan kepada taksis. Adapun indikator pernyataan yang ti-dak boleh diakhirkan penjelasannya, dan yang penjelasannya diperluas/dikembangkan, pada akhirnya ketika dibutuhkan oleh jumhur, maka tidak ada keraguan, sesungguhnya pendapat-pendapat tentang ini pada masa Rasulullah saw., membutuhkan pengetahuan atas hukum perbuatan, jika yang dimaksudkan adalah lafaz Am dari akibat memakan riba, menghalalkan dengan semacamnya disepakati tidak boleh. Dan ini tidak diketahui kecuali Nabi Saw ssesudah wafat dan umat memperbincangkannya, pada semua poin-poin yang umum itu.

Dalam Konteks al-mutlaq wa al-muqayyad, ia mengatakan:

فانه في حال القيد لم يكن مطلقا . وهو لا يقضي النفي العام اذا كان مطلقا غير مقيد ـ فاما مع القيد فقوله: لا اله الا اللّ اللفظ مطلقا , فكيف يقال : انه

33 Uraian lebih lanjut dan detail dapat dibaca dalam Jaih Mubarok, Metodologi Ijtihad Hukum Islam, Cet I, (Yogyakarta: UII Pres, 2002), h.1-75.

34 Abd al-Rahman Muhammad bin Qaim al-Asmiy, Juz XX., op.cit., h. 271. 


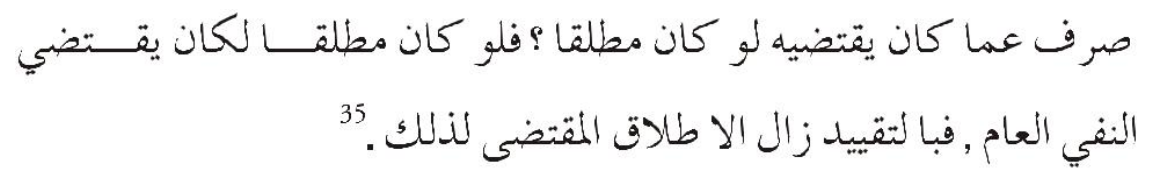

Maka sesungguhnya dalam hal ikatan, tidak ada kemutlakan dan ia tidak dibutuhkan peniadaan secara umum. Apabila kemutlakan itu ti- dak mengikat adanya pernyataan yang mempunyai ikatan لالالالالالال lafaz ini mutlak, bagaimana jika dikatakan ia dapat berubah dari yang ditetapkannya padahal berbentuk mutlak. Seandainya ia mutlak, maka penetapan peniadaan itu sifatnya umum. Oleh karena itu, mu- qayyat yang mengubah yang mutlak itu ditetapkan menurut yang dike- hendaki.

Kedua, Ibnu Taimiyah menggunakan ijtihâd yang berhubungan dengan penggunaan lafal, yang dapat dibedakan menjadi empat, yaitu alhaqiqat (hakikat) dan al-Majaz (majaz). Di antara al-haqiqaat dan almajazI terdapat yang sarih dan al-kinayat. Dalam konteks ini Ibnu Taimiyah dalam kitabnya yang berkenaan dengan usül al-figh terdapat pembahasan khusus mengenai al-Haq qat wa al-Majâz.

\section{b. Ijtihâd Qiyâsi}

Ijtihâd bi al-qiyâsi sering disamakan dengan istilah bi al-ra'yi. Ibnu Qayyim $^{36}$ mengatakan bahwa yang dimaksud dengan ijtihâd bi alra'y adalah penerapan salah satu dari dua atau beberapa illat pada suatu kasus yang mengikat hukum. Sedangkan 'Abd al-Wahab Khallaf $^{37}$ mendefinisikan ijtihâd bi al-ra'y dengan kesungguhan usaha untuk mendapatkan kepastian atau ketentuan hukum sesuatu yang tidak ada ketentuannya dalam nash, dengan berpikir menggunakan beberapa media yang ditunjuk oleh syariat guna menentukan hukum sesuatu yang tidak ada nashnya.

Sedangkan Muhammad Abu Zahrah ${ }^{38}$ menjelaskan ijtihad bi al-ra'y

35 Ibid., Juz XX, h. 457.

36 Ibid., h. 284.

37 Abu Bakr Isma'il Muhammad Miqa, al-Ra'y wa Asaruh fiy Madrasat alMadi-nah, (Beirut: Mu'assasah al-Risalah), h. 31.

38 Abd al-Wahab Khalaf, Madasir al-Tasyri al-Islami firma la nassafih,(t.t: Dar al- 
dengan perenungan dan pemikiran dalam upaya untuk mengetahui sesuatu yang dekat kepada al-Quran dan Sunnah; sama saja apakah ia lebih dekat kepada al-Quran dan Sunnah secara ayat per ayat (ayat dan sunnah tertentu), itulah yang disebut qiyâs, atau ia lebih dekat kepada tujuan umum (global) al-Quran dan Sunnah, dan itulah yang disebut dengan maslahat.

Pada tataran ini, Ibnu Taimiyah dalam melakukan ijtihâd untuk mengeluarkan fatwa melakukan metode ijtihâd bi al-ra'y atau bi al-qiyâs. Qiyâs yang ia gunakan adalah qiyâs $a l-s a h^{3} h$ yang ia bagi dalam dua bentuk yakni: ${ }^{39}$

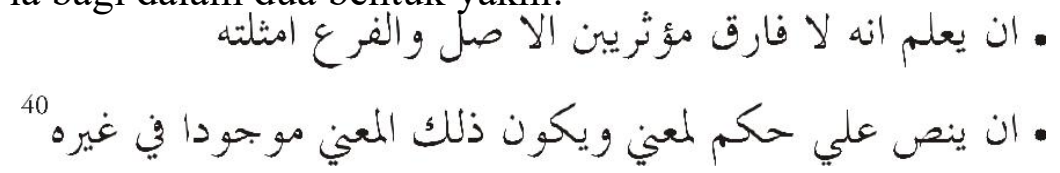

Ibnu Taimiyah juga mengatakan qiyâs $a l-s a h^{3} h$ harus bersesuaian dengan nash. Semua Qiyâs yang bertentangan dengan dalâlah nash menurutnya, adalah qiyâs fâsid. Ia juga mengatakan bahwa tidak ada nash yang bertentangan dengan qiyâs sebagaimana tidak adanya pertentangan antara $\mathrm{ma}^{\prime} q u l \mathrm{sar}^{3} h$ dengan al-manqul al-sah$h^{3} h$.

Dengan kata lain, Ibnu Taimiyah mengatakan bahwa dalam syariat Islam tidak ada sesuatu yang bertentangan dengan qiyâs. Penggunaan qiyâs yang benar tidak mungkin bertentangan, karena semua ajaran Islam memiliki maqâsid al-syari'iyah tersendiri. Maka dari itu, kesalahan dalam perumusan hukum itu sebenarnya kembali kepada kesalahan dalam memahami arti dari suatu nash atau karena interpretasinya yang salah dengan mengabaikan arti yang sebenarnya. ${ }^{41}$

Salah satu aplikasi dari qiyâs adalah terjadinya cakupan makna atas khamar untuk segala yang memabukkan. Berikut salah satu pernya-

Qalam,t.th), h. 7.

39 Muhammad Abu Zahrah, Muhadarat fiy Tarikh al-Mazahib al-Fiqhiyyat, (t.t: Jam'iyyah li Dirasah al-Islamiyyah,t.th), h. 17.

40 Ibnu Taymiyah, Juz XIX, op.cit., h 285-286. Pertama, qiyas yang di dalamnya tidak ada pemisah (fariq) yang mendasar antara furu/cabang (yang diqiyaskan) dengan asl (acuan qiyas). Kedua, bila suatu nas hukum yang mengandung makna isytirak, maka qiyas seperti ini sahih.

41 Ibid., h. 289. 
taannya: ${ }^{42}$

$$
\text { و ومن العلماء من حرم كل مسكر بطريق القــياس : إما في الانســم , وإما في }
$$

${ }^{43}$ Dari pendapat para ulama terhadap keharaman setiap yang memabuk- kan bisa dengan menggunakan cara qiyas, baik dalam Islam maupun dalam hukum, dan cara ini melalui pandangan para fuqaha dari sahabat-sahabat Malik, Syafi'i juga Ahmad. Patut diduga, sesungguhnya dapat disebut qiyas keharaman dari yang memabukkan dan semacamnya, atau diqiyaskan dalam hukum.

Menurut Ibnu Taimiyah, orang yang mengetahui persis maksud redaksi syâri', misalnya kata yang terkandung di dalam redaksi nas itu diketahui musytarak, ia dapat melakukan qiyâs. Sebaliknya bila ia tidak mengetahui tidak ada isytirak, maka ia tidak boleh melakukannya. Misal, haji itu khusus terkait dengan ka'bah, puasa terkait dengan bulan Ramadhan, kiblat itu ka'bah dan lain-lain. Tegasnya tidak bo- leh mengqiyâskan ka'bah dengan benda lain, sehingga tidak ada pe- luang berkesimpulan bahwa ibadah haji boleh dilakukan di tempat lain selain di masjid haram berdasarkan nas adalah qiyâs fasid, seperti mengqiyâskan bangkai dengan hewan yang disembelih dengan nama Allah, atau mengqiyâskan jual beli dengan riba.

Dengan penggunaan qiyâs ini berarti Ibnu Taimiyah menggunakan illat hukum seperti juga ulama lain. Kalau banyak ulama mengatakan bahwa illat terletak pada sifat "mendatangkan kemarahan dan permusuhan, di samping, mudaratnya lebih besar daripada manfaatnya." Illat dalam pendapat pertama disebutkan oleh hadis, sedangkan illat dalam pendapat Ibnu Taimiyah disebutkan dalam al-Quran.

Tampaknya, Ibnu Taimiyah berpandangan bahwa illat hukum

42 Ibid.

43 Ibid., h. 281. 
itu bukan hanya sifat mundabit saja sebagai yang dipedomani oleh ulama $u s u l$ pada umumnya, melainkan sifat-sifat sebagai hikmah yang terkandung dalam hukum yang disebut oleh nas, asal relevan juga dapat menjadi illat hukum. Dalam mencari illat hukum ternyata Ibnu Taymiyah mempunyai pikiran liberal. Liberalitasnya dapat dili- hat ketika ia berbicara hak ijbar wali nikah. Dalam sebuah hadis disebutkan الايماحق بنغس هامنولئيا' hadis ini dipahami oleh para ulama dengan menyatakan bahwa wali mempunyai hak ijbar terhadap anak gadis, dan tidak punya hak ijbar terhadap anak yang sudah janda. Ibnu Taimiyah memiliki pendapat yang berbeda dengan manât ijbar itu tidak terletak pada kegadisan atau kejandaan meskipun teks hadis itu menyebutkan al-ayyim/janda. Namun demikian, kedewasaan seorang wanitalah baik gadis maupun janda yang melepaskan dirinya dari hak ijbar. Sebaliknya, sekalipun ia sudah janda kala belum dewasa, wali tetap mempunyai hak ijbar terhadapnya. Status janda/al-ayyim dalam hadis ini tidak dipahami apa adanya, kendati ia terkenal literalis, tetapi dipahami sebagai "kedewasaan berpikir" yang istilah arabnya rusydah. Dengan tegas ia menyatakan bahwa "baik gadis maupun janda, kalau ia sudah dewasa," tidak seorang pun yang berhak memaksanya untuk menikah. ${ }^{44}$

Selain qiyâs, yang tergolong dalam ijtihâd bi al-qiyâs adalah ijma' istihsân ${ }^{45}$ dan istishâb. ${ }^{46}$ Dari ketiga jenis ini, berdasarkan hasil kajian, penulis berkesimpulan bahwa Ibnu Taimiyah hanya menggunakan satu metode, yaitu ijma', ${ }^{47}$ sedangkan dua metode lainnya tidak digu- nakan.

44 Ibid.,h. 286-287.

45 Ibid., Juz XXXII, h. 22-23.

46 Lihat al-Sarakhsi, Usul-al-Sarakhsi,Juz II, (Beirut: Dar al-Kutub al-Ilmiyyah, 1993), h.200. dan Lihat al-Syatibi, al-Muwafaqat fiy Usul al-Syari'ah, Ed.' Abdullah Darraz. Juz I, (Beirut: Dar al-Kutub al-'Ilmiyyah, 1991), h. 148149. Lihat Ibnu Qudamah Raudah al-Nazir wa Jannah al-Manazir. (Beirut: Mu'asassa al-Risalah,1978), h. 407. Dan juga Lihat 'Abd. Al-Qadir Ahamad Ibn Badran, al-Madkhal Ila al-Mazhab al-Imam Ahmad Ibn Hanbal, (Mesir: Idarah al-Tiba'ah al-Muniriyah, t.th)h. 135-136.

47 Lihat 'Abd al-Wahhab al-Khalaf, Madasir, op.cit.,h. 151. dan lihat Muhammad Abu Zahrah, op., cit., h. 236-237; Wahbah al-Zuhayliy. op. cit., Juz II, h. 867871. 
Salah satu contoh penggunaan ijma' dalam menentukan sebuah hukum adalah ketika ia mengharamkan taklid dengan argumentasi nash dan ijma'. Menurutnya, ${ }^{48}$ tak ada ijma' yang bertentangan de- ngan nash atau tidak mungkin umat bersatu untuk melawan nash ke- cuali ada nas tertentu yang mereka ketahui bahwa nas pertama telah dinasakh. Selanjutnya, ijma' ia bagi dalam dua bagian seperti dalam pernyataannya:

$$
\begin{aligned}
& \text { والاجماع نوعان : قطعي ـ فهذا لا سبيل الى ان يعلم اجماع قطعي على خحلاف النص } \\
& \text { و واما الظين فهو الاجماع الاقر اري و الاستقر ائ : ب أن يستقـــــ افو ال العلماء فلا } \\
& \text { يجد في ذلك خلافا او يشتهر القول في القر ان و لا يعلم احدا انكره ، فهذا الاجماع و ان } \\
& \text { جاز الاحتجاج به فلايجوز ان تدفع النصوص المعلومة به , }
\end{aligned}
$$

Ijma' itu ada dua macam: yaitu yang tidak diketahui jalan atau cara untuk mengetahui ijma' qathiyul dari perbedaan nash. Dan adapun ijma zanniyul adalah ijma' yang disepakati atau disetujui oleh ulama. Tidak ada padanya perbedaan dan tidak ada didapati kontradiksi dengan al-Quran dan tidak ada pendapat yang bertentangan dengan- nya. Ijma ini dibolehkan dipergunakan dan tidak boleh menolaknya dengan nash yang sudah dikenal.

\section{c. Ijtihâd Istilahi (al-Ijtihâd al-Istilahi)}

Ibnu Taimiyah dalam metodologi ijtihâdnya juga menggunakan ijtihâd istiilâhi berupa maslahah al- mursalah. Dikisahkan suatu ketika (di zaman Tartar) Ibnu Taimiyah bersama teman-temannya sedang berjalan di tengah suatu kaum yang sedang minum khamar. Salah seorang teman hendak melarang perbuatan keji mereka itu, tetapi

48 Lihat, Muhammad Hashim Kamali Principles of Islamic Jurisprudence (The Islamis Texs Society), diterjemahkan oleh Noorhaidi dengan judul Prinsip dan Teori Hukum Islam (Ushul al-Fiqh), Cet I, (Yogyakarta: Pustaka Pelajar, 1996) h. 219. Lihat pula Abu Ishak Ibrahim al-Syirazi, al-Luma fi Ushul al-Fiqh (Beirut: Dar al-Kutub al-Ilmiah, t.th).h.87. dan juga Lihat Abd al-Wahhab Khallaf. 'Ilm Ushul al-Fiqh (Kuwait: Dar al-Qalam, 1997), h. 45. dan juga lihat, Ali Yafie, Menggagas Fiqh Sosial: Dari Soal Lingkungan Hidup, Asuransi Hingga Ukhuwah Cet I, (Bandung: Mizan, 1994), h. 76.

49 Ibid., h. 267. 
Ibnu Taimiyah melarangnya. Ia tahu, Allah melarang minum khamar karena dapat mengakitbatkan lalai kepada Allah dan shalat, sedangkan mereka itu minum khamar agar lupa untuk saling bunuh. ${ }^{50}$

Kasus di atas yang membiarkan orang minum khamar bukan karena alasan kemaslahatan umum, tetapi untuk mencegah mereka dari saling membunuh yang memang menjadi kebiasaan mereka. Dalam konteks inilah yang dimaksudkan kemaslahatan oleh Ibn Taimiyah. Hikmah yang dapat diambil dari kisah Ibnu Taimiyah di atas ialah bahwa hukum-hukum syariat tidak berubah karena kebutuhan dan kemaslahatan, tetapi berhenti menerapkannya karena keadaan darurat yang memaksa demikian.

\section{Kesimpulan}

Berdasarkan paparan di atas, maka dapat disimpulkan sebagai ber- ikut:

1. Ibnu Taimiyah bernama lengkap Taqiy al- $D^{3} n$ Abu al-Abbâs Ahmad 'Abd al-Hal'3m bin al-'mâm Majd al-D³n Abi al-Barakah 'Abd al-Salâm bin Muhammad al-Khudari bin 'Abd. Allah bin Taymiyah al-Harran. Ia lahir pada hari Minggu tanggal 10 Rabi' alAwwal $661 \mathrm{H}$. Bertepatan dengan tanggal 22 Januari 1263 M. Adapun guru adalah: Ibn Abd al-Qâwi (603-699H), Ibn Abd alDâ'im (577-678H), Al-Munâja bin Usmân al-Tanukhi (611-695 H), Ibn Qudamah (597-682 H). Sedangkan murid Ibnu Taimiyah adalah Ibn Qayyim al-Jauziyyah (w.751 H), Al-Zahabi (701748 H.), Ibn Kat£³r (701-774), dan Al-Túfi (lahir 670-an).

2. Sistematika Ibnu Taimiyah dalam berijtihad adalah sumber utama al-Quran, Hadis, Ijma', dan Qiyas berdasarkan urutannya. Begitu juga Ibnu Taimiyah melakukan tiga metode ijtihad, yakni ijtihad bayâni, ijtihad qiyâsi dan ijtihad I itilâhi meskipun tidak secara komprehensif dari berbagai bentuk dari setiap metode. Dengan kata lain, dalam teori umum Ibnu Taimiyah mengenai ijtihad, ia sebenarnya menawarkan metode berpikir induktif (empirik).

50 Mun'in A. Sirry, Sejarah Fikih Islam: Sebuah Pengantar, Cet. I, (Surabaya: Risa- lah Gusti, 1995), h. 171. 
Artinya, untuk mengambil kesimpulan sebuah penelitian, maka harus mencermati yang empirik. Empirik bukan hanya apa yang dilakukan dan yang ditulis oleh orang. Empirik dapat berupa kehidupan sehari-hari atau peristiwa alam, dan juga berupa ayat-ayat dan hadis. 


\section{Daftar Pustaka}

Al-Qurản Karim

Amal, Taufik Adnan, Islam dan Tantangan Modernitas: Studi atas Pemi-kiran.

Hukum Fazlur Rahman, Cet. V, (Bandung: Mizan, 1994).

Al-Assimiy, Abd al-Rahman Muhammad bin Qasim, Majmu'alFatawa Syaikh al-Islam Ibnu Taymiyah, (Saudi Arabia: Mamlakah Saudi Arabia, 1398 H).

Al-Asygar, Umar Sulaiman, Tarikh al-Fiqh al-Islami, (Amman: Dar al-Nafa'is, 1991).

Azhim, Said Abdul, Ibnu Taimiyah al-Tajdîd al-Salafî wa Dakwa alIslâhîyah, yang diterjemahkan oleh Faisal Saleh dkk., dengan Judul Ibnu Taimiyah Pembaharu Salafi dan Dakwah Reformasi, Cet. I, (Ja- karta: Pustaka Al-Kautsar, 2005).

Brockelmann, Carl, History of Islamic Peoples, (London: Rouledge \& Ke- gan Paul Limited, 1994).

Dahlan, Abdul Azis, dkk. Ensiklopedi Hukum Islam, Jilid 2, Cet. I, (Jakarta: PT. Ichtiar Baru Van Hoeve, 1997).

Al-Dawalibi, Muhammad Ma'aruf, al-Madkhal Ila al-Tasyri' al-Islami, (Beirut: Mu'assasah al-Risalah, 1989).

Dewan Redaksi Ensiklopedi Islam, Ensiklopedi Islam, Cet. III, (Jakarta: Ichtiar Baru Van Hoeve, 1994).

Gibb, H.A.R., dan J.H. Kramers, "Ibn Taymiyah", Shorter Encyclopedia of Islam, (Leiden: E.J. Brill-London LUZA \& CO, 1961).

Glasse, Cyrill, The Concise Encyclopedia of Islam, diterjemahkan oleh Ghufran A. Mas'adi dengan judul Ensiklopedi Islam (Ringkas), Cet. II, (Jakarta PT. Raja Grafindo Persada, 1999).

Hasan, Ahmad, Pintu Ijtihad Sebelum tertutup, terjemahan. A. Garnadi, (Bandung: Pustaka, 1984).

Ibnu Badran, Abd. Al-Qadir Ahamad, al-Madkhal Ila al-Mazhab al-Imam Ahmad Ibn Hanbal, (Mesir: Idarah al-Tiba'ah al-Muniriyah, t.th).

Ibnu Qudamah, Raudah al-Nazir wa Jannah al-Manazir. Beirut: Mu'asassa 
al-Risalah,1978.

Ibnu Taimiyah, Al-Imam, yang diterjemahkan oleh Kathur Suhardi, Cet. III, (Jakarta: Darul Falah, 2007).

Al-Jauziyah, Ibnu Qayyim, I'lam al-muwaqqi'in 'an Rabb al-'Alamin, Juz III, (Beirut: Dar al-Fikr. t.th).

Kamali, Muhammad Hashim, Principles of Islamic Jurisprudence (The Islamis Texs Society), diterjemahkan oleh Noorhaidi dengan judul Prinsip dan Teori Hukum Islam (Ushul al-Figh), Cet. I, (Yogyakarta: Pustaka Pelajar, 1996).

Khallaf, Abd al-Wahab, Madasir al-Tasyri al-Islami firma la nassafih, (t.t: Dar al-Qalam, t.th). , 'Ilm Ushul al-Fiqh, (Kuwait: Dar al-Qalam, 1997).

Madjid, Nurcholish, Kaki Langit Peradaban Islam, Cet. I, (Jakarta: Para- madina, 1997).

Madkur, Muhammad Salam, Manahij al-Ijtihad fiy al-Islam, (Kuwait: Uni- versitas Kuwait, 1974). , Khasanah Intelektual Islam, (Jakarta: Bulan Bintang, 1984).

Miqa, Abu Bakr Isma'il Muhammad, al-Ra'y wa Asaruh fiy Madrasat al-Madinah, (Beirut: Mu'assasah al-Risalah, t.th).

Mubarok, Jaih, Sejarah dan Perkembangan Hukum Islam, Cet. I, (Bandung: PT. Remaja Rosdakarya, 2000). , Metodologi Ijtihad Hukum Islam, Cet I, (Yogyakarta: UII Press, 2002).

Mudzhar, Atho, "Fiqh dan Reaktualisasi Ajaran Islam", dalam Budhy Munawar Rachan (Ed), Kontekstualisasi Doktrin Islam dalam Sejarah Cet. II, (Jakarta: Paramadina, 1995).

, Membaca Gelombang Ijtidad: Antara Tradisi dan Liberasi, Cet. I, (Jakarta: Titian Ilahi Press, 1998).

Musa, Muhammad Kamil, al-Madhkal Ila al-Tasyri' al-Islam, (Beirut: Muasassah al-Risalah. 1989).

Praja, Juhaya S., "Dinamika Pemikiran Hukum Islam” dalam Jaih Mubarok, Sejarah dan perkembangan Hukum Islam, Cet. I, (Bandung: PT. Remaja Rosdakarya. 2000). 
Rasyidi, H.M., Keutamaan Hukuk Islam, (Jakarta: Bulan Bintang, 1980.

Al-Sayyis, Muhammad 'Ali, Nasy'ah al-Fiqh al-Ijtihadi wa Atwaruh, (t.tp; Majma' al-Buhus al-Ismiyyah, 1970).

Al-Sarakhsi, Usul-al-Sarakhsi, Juz II, (Beirut: Dar al-Kutub alIlmiyyah, 1993).

Ash-Shiddieqy, Hasbi Pengantar Hukum Islam, Vol. 1, (Jakarta:

Bulan Bin- tang, 1980).

Al-Syatibi, al-Muwafaqat fiy Usul al-Syari'ah, disunting oleh Abdullah Darraz, Juz I, (Beirut: Dar al-Kutub al-'Ilmiyyah, 1991). Al-Syirazi, Abu Ishak Ibrahim, al-Luma fi Ushul al-Fiqh, (Beirut: Dar al-Kutub al-Ilmiah, t.th).

Yafie, Ali, Menggagas Fiqh Sosial: Dari Soal Lingkungan Hidup, Asuransi hingga Ukhuwah, Cet I, (Bandung: Mizan, 1994).

Zahrah, Muhammad Abu, Muhadarat fiy Tarikh al-Mazahib al-Fiqhiyyat, (t.t: Jam'iyyah li Dirasah al-Islamiyyah, t.th). 